DENICAR LINA NASCIMENTO FABRIS MAEDA

\title{
IDENTIFICAÇÃO DE EPÍTOPOS PRESENTES NA PROTEÍNA E DO VÍRUS DENGUE TIPO 2 (DENV2) CAPAZES DE GERAR ANTICORPOS NEUTRALIZANTES SEM A PROMOÇÃO DA EXACERBAÇÃO DA REPLICAÇÃO VIRAL
}

Tese apresentada ao Programa de Pós-Graduação em Biologia da Relação Patógeno-Hospedeiro do Instituto de Ciências Biomédicas da Universidade de São Paulo, para obtenção do título de Doutor em Ciências.

Área de concentração: Biologia da Relação Patógeno-Hospedeiro.

Orientador: Prof. Dr. Luís Carlos de Souza Ferreira

Versão corrigida. Versão original encontra-se na unidade que aloja o Programa de Pós-Graduação.

São Paulo 


\section{RESUMO}

MAEDA, D. N. L. F. Identificação de epítopos presentes na proteína $\mathbf{E}$ do vírus Dengue tipo 2 (DENV2) capazes de gerar anticorpos neutralizantes sem a promoção da exacerbação da replicação viral. 2018. 134 f. Tese (Doutorado em Biologia da Relação Patógeno-Hospedeiro) - Instituto de Ciências Biomédicas, Universidade de São Paulo, São Paulo, 2018.

A dengue é uma doença causada por um dos quatro sorotipos de vírus da dengue (DENV 1-4), e representa a principal arbovirose que atualmente atinge seres humanos. Dentre as maiores dificuldades para o desenvolvimento de uma vacina eficaz contra o DENV, correlaciona-se a falta de conhecimento mais preciso sobre os epítopos presentes na superfície do vírus, responsáveis para indução de anticorpos neutralizantes sem promoverem a exacerbação da infecção viral. Desta forma, o objetivo do presente trabalho foi identificar epítopos presentes na superfície do DENV2 capazes de gerar anticorpos neutralizantes sem promover a amplificação viral frente a células que expressem receptores FcyR. Avaliamos também a influência dos adjuvantes (LT, LT-K63 e LTB), na modulação da resposta de anticorpos para epítopos presentes nos domínios I, II e III da proteína de envelope do DENV2. Observamos que a administração das LTs como adjuvantes proporcionaram a potencialização da resposta de anticorpos IgG EDI/II ou EDIII-específicos nos animais imunizados, em relação aos outros grupos vacinais. Em relação à qualidade da resposta humoral proporcionada pelas imunizações, os anticorpos antígeno-específicos gerados com LT, LT-K63 ou LTB apresentaram maior capacidade de neutralização viral em comparação com aqueles obtidos dos demais grupos vacinais. Demonstramos de forma inédita através da análise de imunoassinatura dos anticorpos IgG EDIII-específicos, que a administração de LT e LTB como adjuvante vacinal, permitiu a identificação de um epítopo localizado na alça EF e FG da proteína EDIII de DENV2. Além disso, por meio da utilização do peptídeo 47 contendo a sequência correspondente ao epítopo identificado, foi capaz de inibir a infecção do DENV2, tão bem quanto a proteína EDIII em ensaios in vitro. Podemos perceber, que a utilização do adjuvante LT e seu derivado atóxico LTB em formulações vacinais, possibilitaram a modulação de anticorpos capazes de reconhecer epítopos presentes no EDIII, importantes para a neutralização viral. Esses resultados, permitem o desenvolvimento de novos antígenos alvos para estratégias vacinas voltadas para o controle dos DENV.

Palavras-chave: Adjuvantes. Anticorpos. Dengue. Neutralização. Proteína de envelope. 


\begin{abstract}
MAEDA, D. N. L. F. Identification of epitopes present in the $\mathbf{E}$ protein of dengue virus type 2 (DENV2) capable of generating neutralizing antibodies without causing exacerbation of viral replication. 2018. 134 p. Thesis (Ph. D thesis Biology of Host-Pathogen) - Instituto de Ciências Biomédicas, Universidade de São Paulo, São Paulo, 2018.

Dengue is a disease caused by one of four dengue virus serotypes (DENV 1-4), represents the main arbovirose that currently affects humans. Among the greatest difficulties for the development of effective vaccine against DENV is the lack of more precise knowledge about the epitopes present at the surface of the virus, responsible for the induction of neutralizing antibodies without promoting the exacerbation of viral infection. Thus, the objective of the present work was to identify epitopes present on the surface of DENV2 capable of generating neutralizing antibodies without promoting viral amplification against cells expressing the Fc $\gamma \mathrm{R}$ receptors. We also evaluated the influence of adjuvants (LT, LT-K63 and LTB) on the modulation of the antibody response to epitopes present in domains I, II and III in envelope protein of DENV2. We have observed that administration of LTs as adjuvants provided potentialization of the antibodies response IgG EDI/II or EDIII-specific in the immunized animals, relative to the other vaccine groups. Regarding the quality of the humoral response provided by the immunizations, the antigen-specific antibodies generated with LT, LT-K63 or LTB presented higher viral neutralization capacity compared to those obtained from the other vaccine groups. We demonstrated through the immunoassay analysis of EDIII-specific IgG antibodies that the administration of LT and LTB as a vaccine adjuvant allowed the identification of an epitope located in the EF and FG loop of the EDIII protein of DENV2. Furthermore, by using the peptide 47 containing the sequence corresponding to the identified epitope, it was able to inhibit DENV2 infection as well as the EDIII protein in vitro assays. The LT adjuvant and its non-toxic derivative LTB in vaccine formulations enabled the modulation of antibodies capable of recognizing epitopes present in EDIII, which are important for viral neutralization. These results allow the development of new target antigens for vaccine strategies aimed at the control of DENV.
\end{abstract}

Keywords: Adjuvants. Antibodies. Dengue. Envelope protein. Neutralization. 


\section{INTRODUÇÃO}

A dengue é uma doença causada por um arbovírus pertencente à família Flaviviridae do gênero Flavivirus. Em torno de 390 milhões de casos de dengue no mundo e dentre esses, aproximadamente 96 milhões de casos desenvolvem formas graves da doença, como síndrome de choque da dengue e a febre hemorrágica da dengue (DHF - dengue hemorrhagic fever), (Figura 1) (CARDOSA, 1998; BHATT et al., 2012; HALSTEAD, 2014; GUZMAN; HARRIS, 2015; GUZMAN et al., 2016). Na maioria dos casos, a infecção pelo vírus dengue (DENV) apresenta-se assintomática. Entretanto, após 4 -7 dias de infecção pode se manifestar sintomas da fase aguda: febre alta e intermitente, dores de cabeça, artralgia, dor abdominal aguda e vômitos. Em alguns casos, a evolução da doença pode resultar nas formas mais graves ou fase crítica, caracterizados por aumento da fragilidade vascular, extravasamento de plasma, coagulopatia e aparecimento de petéquias (DHF). Com a progressão da DHF pode-se evoluir para o desenvolvimento da Síndrome do Choque da dengue (DSS - dengue shock syndrome), caracterizada pela encefalite, insuficiência hepática, coagulação intravascular disseminada, hipotensão, acidose metabólica, leucopenia, dentre outros (GUZMAN; HARRIS, 2015; SCREATON et al., 2015; GUZMAN et al., 2016).

A gravidade da doença secundária está intimamente implicada em quatro fatores envolvidos no controle da infecção. O primeiro fator está relacionado com o perfil imunológico do hospedeiro, ou seja, a capacidade de geração de resposta humoral protetora homotípica por um longo período, acompanhada por um período curto de proteção heterotípica. Após esta fase, em alguns casos, os anticorpos gerados durante uma infecção primária podem levar ao aumento da infecção por outro sorotipo de DENV. Outro fator compreende as mudanças genéticas dos DENV proporcionando um aumento na virulência e escape da resposta anti viral, podendo afetar diretamente seu potencial transmissor no vetor ou o processo da doença em humanos. O terceiro fator descrito envolve alterações genéticas no antígeno leucocitário humano (HLA - human leukocyte antigen), que podem aumentar a susceptibilidade ou resistência do hospedeiro ao DENV. O quarto e último fator abrange a idade da pessoa infectada. Crianças e idosos são considerados grupos risco para desenvolver formas mais graves da doença em infecções secundárias pelo DENV (GUZMAN et al., 2016). 


\subsection{CICLO DE REPLICAÇÃO DO DENV}

Atualmente existem 4 tipos de DENV (DENV1 a DENV4) com aproximadamente $60 \%$ de identidade com relação às suas sequências de aminoácidos (FLIPSE; SMIT, 2015). O DENV é transmitido através da picada do vetor do gênero Aedes, principalmente pela espécie Aedes aegypti. Durante o repasto sanguíneo o vírus DENV é liberado na derme e epiderme e, por meio da interação da proteína de envelope aos receptores celulares, é internalizado para células alvo principalmente por endocitose, em um processo dependente de clatrina. Dentro do endossomo, a redução do $\mathrm{pH}$ promove mudança conformacional da proteína de envelope, o que leva à fusão do envelope viral com a membrana do endossomo e a liberação do capsídeo para o citoplasma celular. O capsídeo então se dissocia, liberando o material genético no citoplasma.

O material genético do DENV é representado por um RNA de fita simples com orientação positiva que codifica três proteínas estruturais: envelope, membrana e capsídeo (E envelope protein, $\mathrm{M}$ - membrane protein $\mathrm{e} \mathrm{C}$ - capsid protein) e sete proteínas não estruturais (NS1-non structural proteins, NS2a, NS2b, NS3, NS4a, NS4b e NS5), ausentes no virion e expressas somente em células infectadas. Por meio da maquinaria de síntese proteica da célula hospedeira, ocorre a tradução do RNA viral em uma poliproteína que posteriormente será clivada e originará as proteínas acima descritas. Algumas dessas proteínas estarão envolvidas na síntese de RNA de fita simples com orientação negativa, que servirá de molde para a amplificação do genoma viral (RNA senso). Em seguida, novos ciclos de tradução das proteínas do DENV serão realizados e as proteínas produzida serão destinadas à morfogênese de novas partículas virais. Após a montagem do complexo de replicação no retículo endoplasmático e replicação do RNA, ocorre a montagem das partículas virais caracterizadas pela presença da proteína prM na superfície, com a finalidade de estabilizar a proteína de envelope prevenindo mudanças conformacionais prematuras. Os virions imaturos são transportados via complexo de Golgi e, durante esse processo, sofrem clivagem da proteína prM pela ação da protease furina, tornando as partículas maduras e, em seguida, liberados da célula infectada, (Figura 1) (PERERA; KUHN, 2008; KAUFMANN; ROSSMANN, 2011; SCREATON et al., 2015; GUZMAN et al., 2016).

\subsection{RESPOSTA IMUNE INATA EM INFECÇÕES PELO DENV}

A resposta imune inata é a primeira linha de defesa contra a infecção causada pelo vírus dengue, sua ativação inicia-se na pele após a inoculação do vírus pelo vetor. A pele é organizada 
em três camadas: epiderme, derme e hipoderme sucessivamente. A replicação do DENV ocorre principalmente nas células residentes na epiderme e derme. A epiderme é composta queratinócitos, melanócitos e um tipo de células dendríticas, denominadas células de Langerhans, que, após ativação, migram para linfonodos drenantes para interação com linfócitos T. A derme possui fibroblastos, células endoteliais, células dendríticas (DC- dendritic cells), macrófagos entre outros tipos celulares (ST. JOHN; ABRAHAM; GUBLER, 2013; GARCIA et al., 2017). As células infectadas pelo DENV são ativadas após reconhecimento do RNA viral pelos receptores intracelulares reconhecedores de padrões moleculares associados a patógenos (PAMPs - pathogen-associated molecular pattern), como receptores do tipo Toll (TLRs - Toll-like receptors) e alguns sensores intracelulares da família de helicases (MDA5 melanoma differentiation-associated protein 5; RIG-1 - retinoic acid-inducible gene 1).

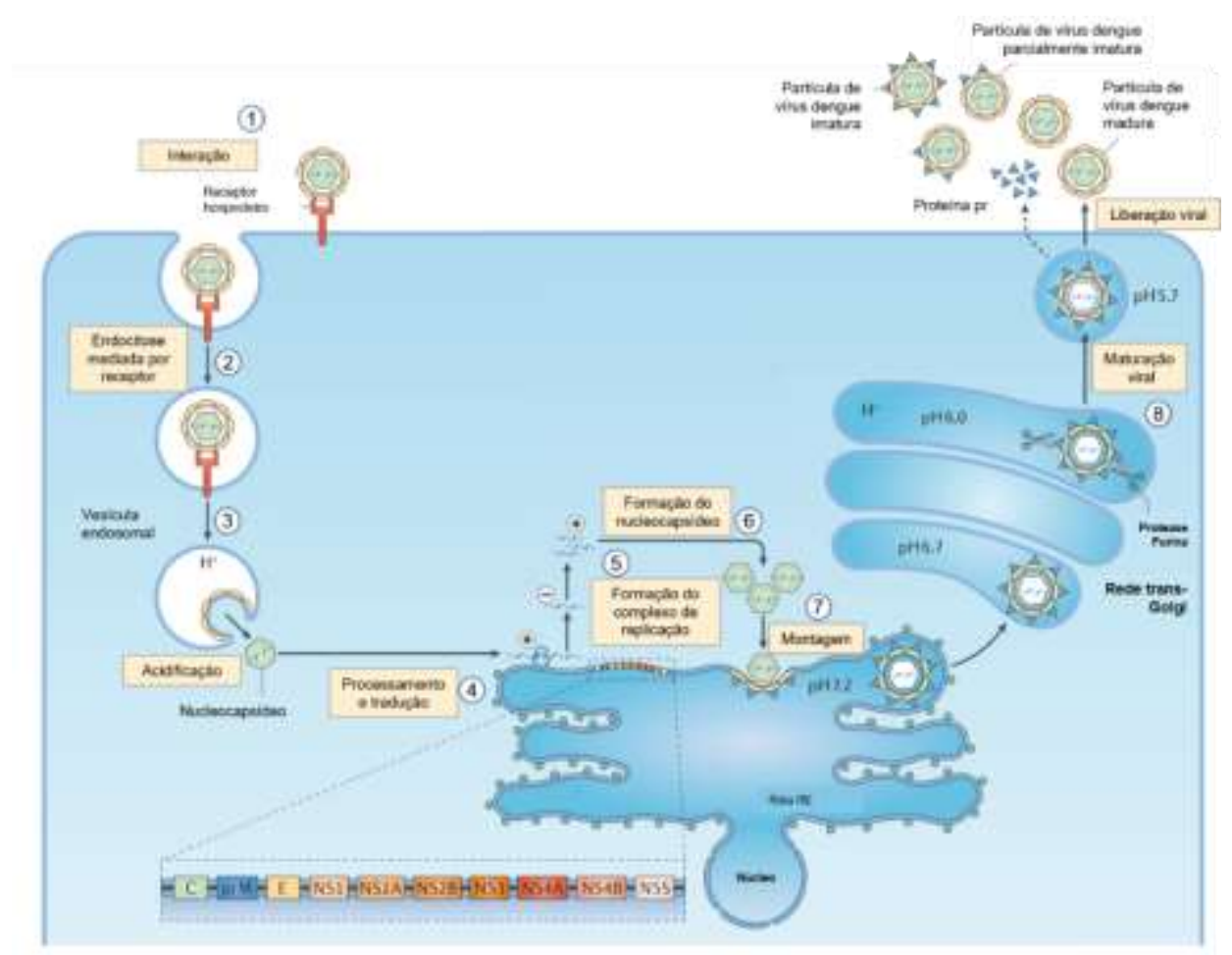

Figura 1. Ciclo de replicação do DENV. O vírus interage com receptores presentes nas células hospedeiras (1) e, subsequentemente, é internalizado via endocitose pela clatrina (2). Com a diminuição do $\mathrm{pH}$ endosomal ocorre mudança conformacional da proteína de envelope que, por sua vez, se funde com a membrana do endossomo e libera o nucleocapsídeo para o citoplasma (3). O RNA livre é traduzido no retículo endoplasmático (RE) para a formação de uma poliproteína contendo 3 proteínas estruturais e 7 proteínas não-estruturais (4). Ocorre a formação do complexo de replicação (5) e o RNA replicado é incorporado ao nucleocapsídeo (6) para montagem das partículas virais (7). Os virions imaturos são transportados via complexo Golgi e, após clivagem pela protease Furina (maturação), são liberados da célula hospedeira (8). Fonte: modificado de Screaton et al., 2015.

A ativação via o TLR3 ocorre após o processo de acidificação do ambiente endosomal e por meio da sinalização de vias intracelulares mediadas pelo adaptador induzido por interferon $\beta$ (TRIF - TIR - domain-containing adapter-inducing interferon- $\beta$ ), promovendo uma forte 
expressão das interleucinas (IL) IL1- $\beta$, IL-6, IL-8 e fator de necrose tumoral (TNF - tumor necrosis factor), bem como respostas mediadas por interferon tipo I $\alpha / \beta$ (INF- $\alpha / \beta)$. Além do TLR3, o RNA viral pode ativar o TLR-7 que também está presente no endossomo, entretanto o processo de sinalização da cascata é mediada pela molécula adaptadora de diferenciação mielóide (MYD88 - Myeloid differentiation primary response 88), desencadeando a produção de TNF, IL-6 e INF- $\alpha$ (GREEN et al., 2015; GUZMAN; HARRIS, 2015; GARCIA et al., 2017; SPROKHOLT; HELGERS; GEIJTENBEEK, 2018).

Os sensores citoplasmáticos RIG-1 e MDA-5 têm demonstrado um importante papel em respostas anti-DENV, principalmente em células DC e macrófagos infectados. Essas moléculas induzem respostas imunológicas via proteínas sinalizadoras antivirais mitocondriais (MAVS Mitochondrial antiviral-signaling protein), favorecendo produção de IL-1 $\beta$, IL-6 TNF e INF tipo 1 e INF tipo 2 (INF- $\gamma$ ). Em DCs maduras, os sensores RIG-1 e MDA-5 promovem a expressão de moléculas coestimulatórias do grupo de diferenciação (CD - cluster of differentiation) 80, CD83, CD86, CD40 e moléculas do complexo principal de histocompatibilidade (MHC - major histocompatibility complex) I e II, importantes para a resposta imunológica adaptativa (GREEN et al., 2015; SPROKHOLT; HELGERS; GEIJTENBEEK, 2018).

\subsection{RESPOSTA IMUNE ADAPTATIVA CONTRA O DENV}

A resposta imunológica adaptativa mediada pela ativação de linfócitos $\mathrm{B}$ e principalmente T são cruciais para a proteção contra infecção causada pelo DENV. Inicialmente durante a resposta primária, ocorre a indução da expansão de linfócitos TCD4+ e TCD8 ${ }^{+}$ citotóxicos de memória sorotipo-específica e com reatividade cruzada. Em uma segunda exposição ao DENV, essas células se expandem e rapidamente desencadeiam a ativação de linfócitos T auxiliares ( $\mathrm{Th}-$ T helper), que por sua vez, aumentam a produção de INF- $\gamma$, TNF, IL-12 e a expressão de CD107a. O aumento da expressão de INF- $\gamma$ e CD107a promove a lise de células infectadas pelo DENV (WEISKOPF; SETTE, 2014; RIVINO, 2016; SPROKHOLT; HELGERS; GEIJTENBEEK, 2018). Em alguns trabalhos foram descritas regiões imunodominantes presentes nas proteínas de DENV com papel importante para a ativação de linfócitos $\mathrm{TCD}^{+}$e $\mathrm{TCD}^{+}$citotóxicos pelas DCs. Para linfócitos $\mathrm{TCD}^{+}$, os epítopos imunodominantes estão presentes majoritariamente nas proteínas não estruturais NS3 e NS5, enquanto que para a ativação de linfócitos $\mathrm{TCD}^{+}$, regiões presentes nas proteínas NS1, 
capsídeo e envelope viral mostram-se mais relevantes (MALAVIGE; OGG, 2013; MATHEW; TOWNSLEY; ENNIS, 2014).

A ativação de linfócitos $B$ durante a infecção pelo DENV pode ocorrer de forma $T$ independente ou dependente. Durante o processo infeccioso, o DENV pode ser drenado para linfonodos próximos e promover a ativação e expansão das células imunológicas, proporcionando a formação do centro germinativo ( $\mathrm{GC}$ - germinal centers) no linfonodo. Os linfócitos B imaturos DENV-específicos podem ser ativados após interação de seus receptores de superfície com o vírus, promovendo a expansão de plasmócitos extrafolicular de vida curta produtoras de IgM. Por outro lado, a ativação T-dependente de linfócitos B ocorre com a participação dos linfócitos Th foliculares que ao produzirem citocinas promovem a troca de classe de anticorpos antígeno-específicos e expansão de linfócitos B altamente específicos em plasmócitos de vida longa e linfócitos B de memória. Os anticorpos secretados pelos linfócitos B reconhecem em sua maioria epítopos presentes em toda a superfície da proteína de envelope, entretanto, também há a produção de anticorpos direcionados para a proteína prM e para proteínas não estruturais (PHYSIOL et al., 2013; VANBLARGAN; GOO; PIERSON, 2016; YAM-PUC et al., 2016).

\subsection{ESTRUTURA DA GLICOPROTEÍNA DE ENVELOPE VIRAL E MECANISMO DE NEUTRALIZAÇÃO}

A proteína de envelope (53 kDa) é considerada um importante fator antigênico do DENV para indução de anticorpos neutralizantes. A superfície viral apresenta 90 homodímeros de proteína de envelope e cada monômero da proteína apresenta três domínios: I (EDI estrutura em $\beta$-barril presente na região central da molécula), II (EDII - domínio que compreende o peptídeo de fusão) e III (EDIII - porção C-terminal tipo-imunoglobulina), (Figura 2A). A proteína de envelope também apresenta dois sítios de $N$-glicosilação (cadeias de carboidratos ligados ao aminoácido asparagina): Asn-67, encontrada apenas em DENV e Asn-153, conservada em todos os Flavivirus (CRUZ-OLIVEIRA et al., 2015a; MONDOTTE et al., 2007; ZHANG; BOOTH, 2010; ZHANG et al., 2012). Os domínios da proteína de envelope são essenciais para o processo de infecção nas células hospedeiras e o processo iniciase pela ligação do EDIII em receptores presentes na superfície celular. A capacidade do DENV em infectar vários tipos celulares está relacionada às características intrínsecas do EDIII em interagir com diferentes receptores, como por exemplo, heparan sulfato, receptor de manose da família de lectinas tipo-C, moléculas de adesão de DCs (DC-SIGN - Dendritic Cell- 
Specific Intercellular adhesion molecule-3-Grabbing Non-integrin), receptor de manose em macrófagos (MR - manose receptor), receptor CD14, proteínas induzidas por estresse HSP70 e HSP90, dentre outras (CRUZ-OLIVEIRA et al., 2015b). Após internalização, a vesícula contendo a partícula viral se funde rapidamente com o endossomo e em ambiente ácido (pH 5,8 - 6,6) ocorre mudanças conformacionais nos domínios da proteína de envelope acarretando na formação de trímeros, expondo assim o peptídeo de fusão do EDII que, por sua vez, se funde à membrana do endossomo liberando o capsídeo viral, (Figura 2A) (MUKHOPADHYAY; KUHN; ROSSMANN, 2005; KAUFMANN; ROSSMANN, 2011; SMIT et al., 2011; HEINZ; STIASNY, 2012).

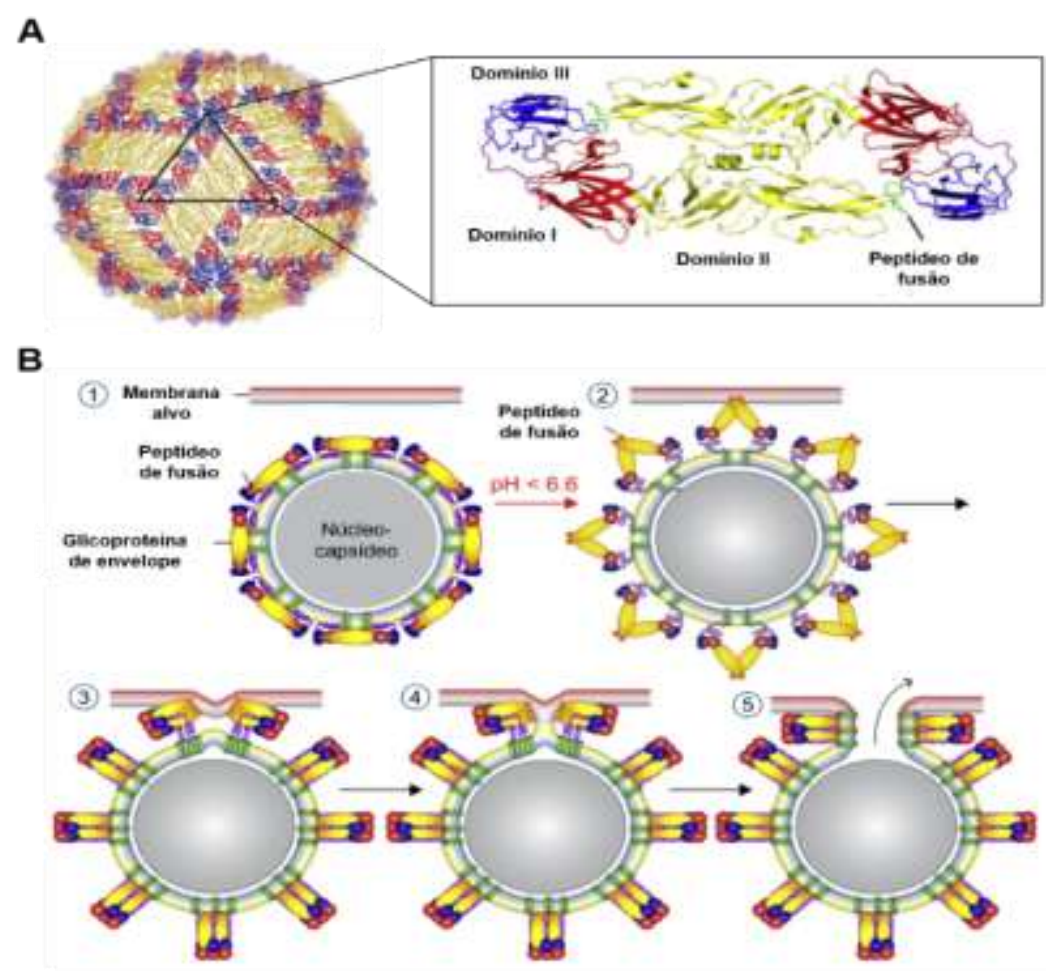

Figura 2. Proteína de envelope do DENV. Representação esquemática da glicoproteína de E. (A) Diagrama de cores dos domínios da proteína de envelope: EDI, $\beta$-barril presente na região central da molécula (vermelho); EDII, domínio contendo o peptídeo de fusão (amarelo) e EDIII, porção C-terminal (azul). (B) Processo de fusão da proteína de envelope viral com a membrana do endossomo: (1), Homodímeros de E na superfície do DENV; (2), com o pH endosomal baixo, ocorre mudança conformacional nos domínio da proteína de envelope e interação com a membrana do endossomo; (3) formação do trímero; (4) hemifusão intermediária com a membrana do endossomo; (5) Abertura do poro de fusão e liberação do nucleocapsídeo para o citoplasma da célula hospedeira. Fonte: modificado de Heiz e Stiasny, 2012; Kaufmann e Rossman, 2011.

O mecanismo de neutralização por anticorpos DENV-específicos pode ocorrer por bloqueio da ligação da partícula viral com a célula hospedeira, pela interação dos anticorpos específicos a epítopos presentes no EDIII, ou à ligação a cadeias de carboidratos, importantes para ligação da partícula viral à determinados receptores celulares reconhecedores de carboidratos. Outra forma, seria o bloqueio do processo de mudança conformacional da proteína de envelope no endossomo levando exposição da região de fusão no EDII (PIERSON; 
DIAMOND, 2008; FLIPSE; SMIT, 2015; SPROKHOLT; HELGERS; GEIJTENBEEK, 2018). A potência de neutralização está relacionada ao número requerido de anticorpos opsonizantes capazes de exceder sua estequiometria, para isto, dois fatores são determinantes. O primeiro fator está relacionado com a força de ligação (afinidade) dos anticorpos. Foi demonstrado que anticorpos com alta capacidade neutralizante apresentam baixa ocupância viral. Entretanto alguns anticorpos com alta afinidade ao epítopo demonstram capacidade de neutralização reduzida, necessitando de altas concentrações para observação do efeito, (Figura 3) (KLASSE; SATTENTAU, 2002; PIERSON; DIAMOND, 2008; PIERSON et al., 2009a; VAN DER SCHAAR; WILSCHUT; SMIT, 2009). O segundo fator pertinente a capacidade de neutralização dos anticorpos é a acessibilidade a epítopos quaternários e crípticos presentes na superfície do DENV. Os vírus são estruturas dinâmicas e apresentam mudanças na exposição de epítopos de superfície pelo fenômeno denominado "respiração viral", que pode ser influenciado pelo estado de maturação da partícula viral, temperatura, $\mathrm{pH}$ e variação de sequência entre os flavivírus, (Figura 3) (PIERSON; DIAMOND, 2008; PIERSON et al., 2009b; KUHN et al., 2015; VANBLARGAN; GOO; PIERSON, 2016).

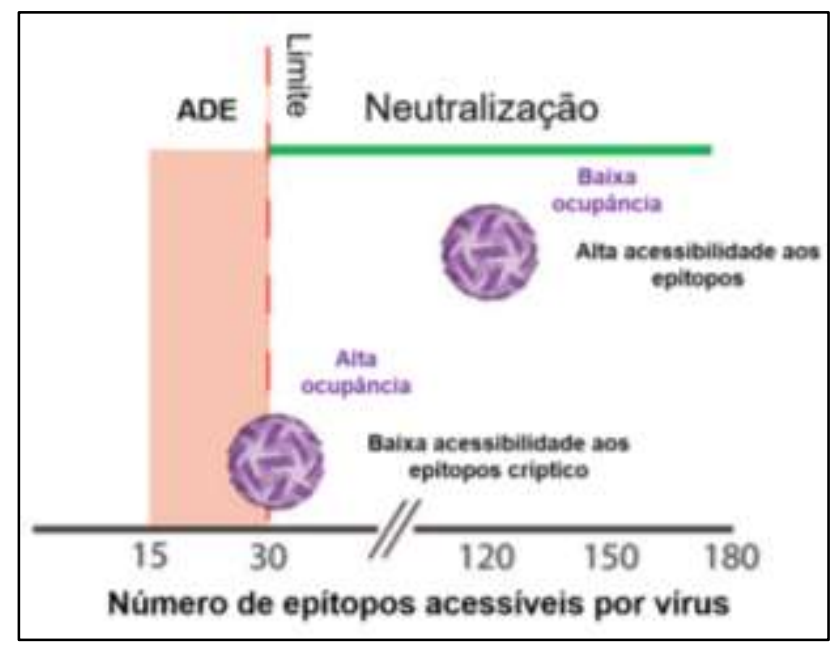

Figura 3. Modelo de relação entre acessibilidade de epítopo e ocupância reque rida para neutralização. Os números de anticorpos ligados ao vírus são modulados pela afinidade do anticorpo e acessibilidade por epítopos. Anticorpos que se ligam em epítopos pouco acessíveis (crípticos) não são capazes de alcançar a estequiometria necessária, mesmo com alta afinidade precisam de alta ocupância para a neutralização. Em contrapartida anticorpos que ligam a epítopos acessíveis na partícula vir al podem excedem seu limite estequiométrico para neutralização e apresentarem baixa ocupância. O ADE pode ocorrer quando a quantidade de anticorpos necessários não atinge o limiar estequiométrico necessário para a neutralização. Fonte: modificado de Vanblargan, Goo e Pierson, 2016.

Além da capacidade de neutralização devido à interação da região variável (Fab Fragment antigen binding) com a partícula viral, anticorpos IgG podem desencadear respostas antivirais mediada por sua porção constante ( $\mathrm{Fc}$-fragment crystallizable) - região de ligação com receptores específicos presentes na superfície de células do sistema imunológico em 
processo envolvendo a atividade conjunta com os componentes da resposta imunológica inata e que desencadeia outros mecanismos efetores. Os vírus opsonizados podem ativar a via clássica do sistema complemento por meio da interação com o componente C1q, C4b e C3b, promovendo a lise direta da partícula viral. Entretanto, devido ao pequeno tamanho de superfície dos Flavivirus esse mecanismo pode ser prejudicado (CHAN et al., 2015; GUILLIAMS et al., 2014). As partículas virais opsonizadas podem também promover a ativação de células fagocíticas (monócitos, macrófagos e Dc) por meio da interação da porção Fc dos anticorpos a receptores específicos presentes na superfície dessas células e levar à citotoxicidade celular dependente de anticorpos (ADCC - antibody dependent cell mediated cytotoxicity). Nesse processo, anticorpos ligados a antígenos presentes na superfície de células infectadas promovem a ativação de células matadoras profissionais (NK - natural killers) que, por sua vez, liberam substâncias desencadeadoras de morte da célula infectada (CHAN et al., 2015).

Os anticorpos da classe IgG interagem com receptores Fc específicos $(\mathrm{Fc} \gamma \mathrm{R}-\mathrm{Fc}$ gamma receptors) do tipo I, divididos de acordo com sua afinidade e moléculas envolvidas no processo de resposta celular. Os receptores $\mathrm{Fc} \gamma \mathrm{R}$ de alta afinidade $(\mathrm{Fc} \gamma \mathrm{RI})$ ligam-se à $\mathrm{IgG}$ monomérica antes ou depois de sua ligação com o antígeno (imunocomplexos), enquanto os FcyR de baixa

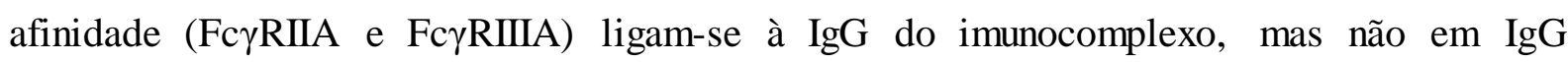
monomérica. Além disso, esses receptores são divididos de acordo com a capacidade de ativação ou inibição de respostas por células imunológicas (CHAN et al., 2015; GUILLIAMS et al., 2014).

Os receptores Fc $\gamma$ RI, Fc $\gamma$ RIIA e Fc $\gamma$ RIIIA requerem para a transdução do sinal uma porção sinalizadora ativatória rica em tirosina (ITAM - immunoreceptor tyrosine-based activation motif). Nos receptores Fc $\gamma$ RI e Fc $\gamma$ RIIIA, o ITAM está localizado na membrana formando uma molécula acessória. No receptor para Fc $\gamma$ RIIA, a porção ITAM está localizada em sua própria cadeia na porção intracelular. Os receptores Fc $\gamma \mathrm{RIIB}$ apresentam características inibidoras, pois possuem uma porção sinalizadora inibidora rica em tirosina (ITIM immunoreceptor tyrosine-based inhibitorymotif), presente na sua cadeia na porção intracelular (CHAN et al., 2015; GUILLIAMS et al., 2014). Existe uma variação na expressão desses receptores de acordo com o tipo de células imunológicas. Monócitos e macrófagos expressam os receptores Fc $\gamma$ RI, Fc $\gamma$ RIIA, Fc $\gamma$ RIIB e Fc $\gamma$ RIIIA; DCs expressam os receptores Fc $\gamma$ RIIA,

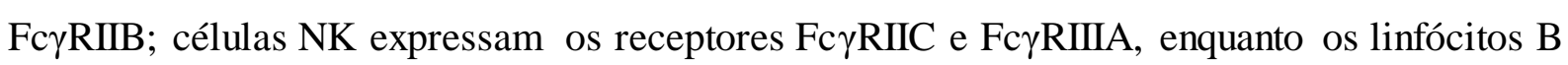
expressam FcyRIIB (BOURNAZOS; RAVETCH, 2017a; BOURNAZOS; RAVETCH, 
2017b). Os receptores FcyR tipo I apresentam várias funções nas células imunológicas auxiliando no processamento de imunocomplexos, modulação da polarização de macrófagos e modulação na apresentação de antígeno pelas DCs alterando o perfil de resposta imunológica adaptativa antígeno-específica (GUILLIAMS et al., 2014).

Os receptores Fc $\gamma \mathrm{R}$ também podem ser do tipo II, pertencente à família de lectinas tipo C, e representados pelo CD23 e DC-SIGN, presentes principalmente em DCs e com capacidade de interagir com uma variedade de moléculas, incluindo carboidratos. $\mathrm{O}$ receptor com maior relevância em infecções pelo DENV é o receptor DC-SIGN presentes em DCs e podem promover a infecção de forma independente ou depende de anticorpos. O receptor DC-SIGN é composto por um domínio citoplasmático, domínio extracelular com 23 resíduos de aminoácidos repetidos e por um domínio C-terminal reconhecedor de carboidratos (CDR carbohydrate recognition domain), sua ativação culmina na indução de várias rotas imunoestimuladoras nas DCs (POKIDYSHEVA et al., 2006; BOURNAZOS; RAVETCH, 2017b).

\subsection{AUMENTO DA INFECÇÃO VIRAL MEDIADA POR ANTICORPOS}

Em algumas respostas mediadas pelos receptores $\mathrm{Fc} \gamma \mathrm{R}$ do tipo 1 foi observado que anticorpos pré-existentes podem ser incapazes de neutralizar outro sorotipo de DENV, favorecendo o direcionamento do vírus para uma via que culmina na replicação viral intracelular nas células fagocíticas. Este fenômeno é conhecido como aumento da infecção viral mediada por anticorpos não neutralizantes (ADE - antibody-dependent enhancemente), (Figura 4). A primeira constatação do fenômeno para o DENV foi descrita por Halstead e O’Rourke (1977), pela observação do aumento de infecção por DENV em monócitos e macrófagos primários na presença de anticorpos não neutralizantes. De acordo com a observação, uma segunda infecção por sorotipo diferente do vírus poderia ser exacerbada pela ligação de anticorpos gerados durante a primeira infecção. Esse processo facilitaria a entrada dos vírus em novas células do hospedeiro, proporcionando o aumento da carga viral, intensidade da resposta inflamatória e danos em células endoteliais que, em conjunto, causariam a forma hemorrágica da doença (HALSTEAD, 1977; WHITEHEAD et al., 2007; GUZMAN et al., 2010).

O fenômeno de ADE pode ocorrer quando a quantidade necessária de anticorpos Eespecíficos não atinge o limiar estequiométrico necessário para a neutralização viral, (Figura 3). As partículas de DENV maduras apresentam diferenças na organização da proteína de 
envelope em comparação às partículas parcialmente ou totalmente imaturas apresentando proteína $\mathrm{E}$ ligada à proteína prM. Essa divergência estrutural pode prejudicar a acessibilidade a epítopos presentes na superfície da proteína de envelope, bem como, afetar o limiar estequiométrico dos anticorpos necessário para a neutralização (FLIPSE; WILSCHUT; SMIT, 2013). As partículas de DENV imaturas são incapazes de infectar as células imunológicas pela interação com receptores convencionais para infecção. Entretanto, foi demonstrado que a presença de anticorpos prM-específicos podem propiciar a entrada de partículas parcialmente imaturas na célula após interação com receptores FçR (RODENHUIS-ZYBERT et al., 2010; FLIPSE; WILSCHUT; SMIT, 2013; FLIPSE; SMIT, 2015). Dentro do endossomo celular pode ocorrer mudança conformacional nos heterodímeros prM/E, facilitando a clivagem da proteína prM na superfície das partículas imaturas. Desta forma, o DENV maduro com a proteína E trimérica pode interagir com a membrana do endossomo liberando o capsídeo viral no citoplasma da célula hospedeira, (Figura 4) (FLIPSE; WILSCHUT; SMIT, 2013).

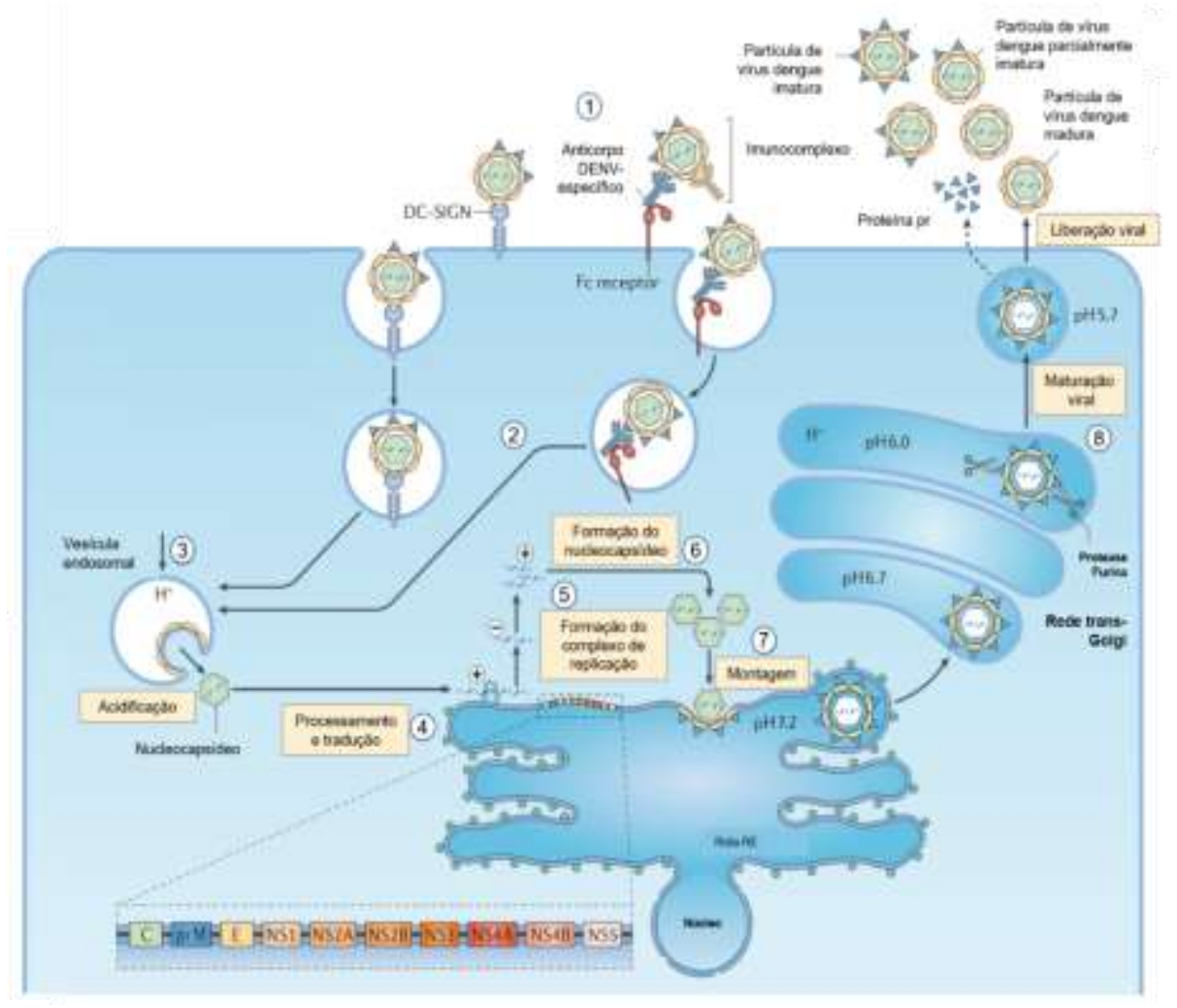

Figura 4. Aumento da infecção me diada por receptores FcyR. Partículas virais parcialmente imaturas podem interagir com anticorpos anti-prM capazes de ligar em receptores Fc $\gamma R$, ou através da ligação direta com receptores DC-SIGN (1) e, subsequentemente, serem internalizados (2). Com a diminuição do $\mathrm{pH}$ endosomal ocorre a mudança conformacional do heterodímero $\mathrm{prM} / \mathrm{E}$ facilitando a clivagem da proteína $\mathrm{prM}$ pela furina, consequentemente ocorre a fusão da proteína de envelope viral com a membrana do endossomo e liberação do nucleocapsídeo no citoplasma (3). O RNA livre e traduzido no retículo endoplasmático (RE) para a formação de uma poliproteína contendo 3 proteínas estruturais e 7 proteínas não-estruturais (4). Ocorre a formação do complexo de replicação (5). Após o RNA replicado e incorporado ao nucleocapsídeo (6), para montagem das partículas virais (7). Os virions imaturos são transportados via complexo Golgi e após clivagem pela protease Furina (maturação) são liberados da célula hospedeira (8). Fonte: modificado de Screaton et al., 2015. 


\subsection{IMPLICAÇÕES NO DESENVOLVIMENTO DE VACINAS CONTRA DENV}

Os mecanismos para indução de resposta protetora contra a dengue ainda não estão bem esclarecidos. Admite-se que o correlato de proteção para infecções desencadeadas pelo DENV seja a indução de resposta imunológicas representada por altos níveis de anticorpos neutralizantes. Entretanto, atualmente existem observações consistentes sobre a importância da participação da resposta imunológica celular no mecanismo de proteção contra infecções causadas pelo vírus. Sendo assim, preconiza-se que uma vacina eficaz e segura para o controle da dengue deve ser capaz de induzir anticorpos neutralizantes e expansão de linfócitos $\mathrm{T}$ específicos capazes de impedir a infecção pelos quatro sorotipos virais e principalmente sem promover o fenômeno de ADE (GUZMAN et al., 2016; WEN; SHRESTA, 2017).

Além dos estudos relacionados aos antígenos ideais para o desenvolvimento de vacinas contra dengue, algumas substâncias empregadas são essenciais para estimular eficientemente o sistema imunológico contra o vírus. Essas substâncias, adjuvantes, podem amplificar, modular e prolongar a imunogenicidade intrínseca de antígenos alvos (coadministrados, conjugados quimicamente ou fusionados geneticamente) melhorando a eficácia das vacinas (PASSOLD; FERREIRA; ZANETTI, 2004; VANUSA et al., 2011).

A toxina termo-lábil (LT - heat labile toxin) da Escherichia coli enterotoxigênica (ETEC - enterotoxigenic Escherichia coli) apresenta uma subunidade A de $27 \mathrm{kDa}$ com atividade enzimática de adenosina difosfato ribosilação (ADP -adenosine diphosphate) e uma subunidade B composta por cinco polipeptídios idênticos (11,5 kDa) estruturados em forma de um anel pentamérico e responsável pela ligação a receptores presentes na superfície das células hospedeiras (FAN et al., 2000; LENCER; SASLOWSKY, 2005). Além de apresentar um importante papel na patogenicidade de ETEC, a LT e seus mutantes ou derivados atóxicos são capazes de induzir potentes respostas imunológicas humorais e celulares antígeno-específica após a administração por diferentes vias (parenteral, transcutânea e de mucosa). Foi descrito que o uso de LTs como adjuvante promove ativação e modulação de linfócitos B secretores de anticorpos IgG séricos e IgA secretado em mucosas associados com a presença de linfócitos $\mathrm{TCD}^{+}{ }^{+}$e TCD8 ${ }^{+}$secretores de citocinas, como INF- $\gamma$, IL-4 IL-5, IL-6 e/ou IL10, e promovem a maturação de DCs proporcionando um aumento na capacidade de apresentação de antígeno via expressão de moléculas co-estimulatórias CD80 e CD86 e produção de IL-1 $\beta$ via ativação dos componentes do inflamassoma culminando no desenvolvimento de células Th17 (FREYTAG; CLEMENTS, 2005; BRERETON et al., 2011; BRAGA et al., 2014; BATISTA et al., 2017). Em estudos relacionados à resposta imunológica humoral induzida pela 
administração de LT e seus mutantes ou derivados atóxicos, a investigação da potência e modulação de resposta é limitada a determinação dos títulos e subclasses de anticorpos antígeno-específicos (HAAN et al., 1999; FRASER et al., 2003). Entretanto, recentemente foi demonstrado que administração das LTs com adjuvantes vacinais, além de potencializar a resposta de anticorpos contra o antígeno, modulou o espectro de reconhecimento de epítopos e induziu anticorpos com maior capacidade de neutralização, reconhecedores de epítopos importantes para resposta contra o patógeno (BATISTA et al., 2017).

$\mathrm{O}$ uso de peptídeos sintéticos tem sido amplamente utilizados em abordagens terapêuticas contra infecções virais, como influenza, HIV e hepatites (SKALICKOVA et al., 2015). Poucos trabalhos buscam investigar o uso de peptídeos no tratamento contra a dengue. Em estudo realizado por Schimidt e colaboradores (2010), peptídeos para a região hidrofóbica da proteína de envelope determinados a partir de analises in silico, foram capazes de inibir a infecção pelo DENV após interação com o domínio EDII durante a formação dos trímeros da proteína E, bloqueando a fusão do envelope viral com a membrana do endossomo da célula hospedeira. De forma semelhante, Alhood e colaboradores (2016) demonstraram que peptídeos alvos para o domínio EDIII, também determinados por análises in silico, são capazes de inibir a ligação do vírus aos receptores da célula hospedeira, por meio de alterações conformacionais na proteína de envelope do DENV2. De fato, poucos trabalhos buscam desenvolver estratégias para identificação de epítopos responsáveis pela indução de anticorpos policlonais neutralizantes sem promover exacerbação da infecção viral em células que expressam receptores FcyR (STIASNY et al., 2006; LEWIS et al., 2009; WAHALA et al., 2009; DE ALWIS et al., 2012; CHAICHANA et al., 2014).

Sabe-se que a resposta humoral gerada contra infecções causadas pelo DENV envolve a expansão de linfócitos $\mathrm{B}$ produtores de anticorpos com vários tipos de especificidade, afinidade a epítopos que, juntamente com outras capacidades funcionais, caracterizam a atividade neutralizante contra o vírus. A compreensão dos mecanismos envolvidos na capacidade neutralizantes dos anticorpos é atualmente estudada principalmente por meio da utilização de anticorpos monoclonais (PIERSON et al., 2009b; DE ALWIS et al., 2012; WILLIAMS et al., 2013). Entretanto, a atividade conjunta dos anticorpos em uma resposta policlonal protetora durante o processo infeccioso ou após vacinação ainda não é bem compreendida.

De fato, uma das principais dificuldades para o desenvolvimento de uma vacina é a falta de conhecimento sobre os principais epítopos alvo para anticorpos neutralizantes na partícula 
viral. Desta forma, o presente estudo tem como objetivo maior a caracterização de epítopos presentes na proteína E do DENV em busca de alvos antigênicos para geração de uma resposta humoral protetora sem causar o fenômeno de ADE. O conhecimento gerado a partir dessa pesquisa deverá permitir que abordagens mais racionais sejam aplicadas no desenvolvimento de vacinas mais eficazes contra a dengue. 


\section{CONCLUSÕES}

A identificação de epítopos reconhecidos por anticorpos com capacidade de neutralização de partículas virais, em especial o DENV, tem sido alvo de pesquisa por vários grupos de pesquisas no mundo, sobretudo por meio da geração de anticorpos monoclonais. Poucos trabalhos buscam compreender o potencial de geração de anticorpos neutralizantes por meio de respostas mediadas por anticorpos policlonais. Com esse intuito, o presente estudo empregou proteínas recombinantes correspondentes a domínios da proteína de envelope (EDI/II e EDIII) de DENV2 para a caracterização de epítopos envolvidos na produção de anticorpos policlonais neutralizantes, bem como, epítopos envolvidos na produção de anticorpos capazes de promover o fenômeno de ADE. Para essas análises, empregamos uma nova metodologia que envolve a definição das imunoassinaturas de anticorpos gerados após imunização com EDIII na presença dos adjuvantes LT ou LTB.

A prevenção de infecções causadas pelo DENV está relacionada ao desenvolvimento de formulações vacinais confiram proporcionem proteção aos 4 sorotipos de DENV. Neste contexto, a escolha de um adjuvante que module a especificidade de anticorpos a epítopos que permitam a neutralização viral sem os riscos associados ao fenômeno de ADE é uma meta importante. Nesse estudo verificamos que o uso de derivados de LT em conjunto com o uso de uma forma recombinante do EDIII permitiu a identificação de epítopo envolvidos na neutralização da infecção viral. A continuidade desses estudos deve buscar entender o papel desta sequência na interação do vírus com as células alvo assim como o potencial vacinal desta região na geração de anticorpos neutralizante desprovidos de efeito ADE. 


\section{REFERÊNCIAS*}

ALHOOT, M. A.; RATHINAM, A. K.; WANG, S. M.; MANIKAM, R.; SEKARAN, S. D. Inhibition of dengue virus entry into target cells using synthetic antiviral peptides. International Journal of Medical Sciences, v. 10, n. 6, p. 719-729, 2013.

AMORIM, J. H.; PEREIRA BIZERRA, R. S.; DOS SANTOS ALVES, R. P.; SBROGIOALMEIDA, M. E.; LEVI, J. E.; CAPURRO, M. L.; DE SOUZA FERREIRA, L. C. A Genetic and Pathologic Study of a DENV2 Clinical Isolate Capable of Inducing Encephalitis and Hematological Disturbances in Immunocompetent Mice. PLoS ONE, v. 7, n. 9, p. 1-12, 2012.

AMORIM, J. H.; PORCHIA, B. F. M. M.; BALAN, A.; CAVALCANTE, R. C. M.; DA COSTA, S. M.; DE BARCELOS ALVES, A. M.; DE SOUZA FERREIRA, L. C. Refolded dengue virus type 2 NS1 protein expressed in Escherichia coli preserves structural and immunological properties of the native protein. Journal of Virological Methods, v. 167, n. 2, p. 186-192, 2010.

AZEVEDO, A. S.; YAMAMURA, A. M. Y.; FREIRE, M. S.; TRINDADE, G. F.; BONALDO, M.; GALLER, R.; ALVES, A. M. B. DNA vaccines against dengue virus type 2 based on truncate envelope protein or its domain III. PloS one, v. 6, n. 7, p. e20528, 2011. Disponível em:

$<$ http://www.pubmedcentral.nih.gov/articlerender.fcgi?artid=3136928\&tool=pmcentrez\&rend ertype $=$ abstract $>$.

BATISTA, M. T.; FERREIRA, E. L.; PEREIRA, G. de S.; STAFFORD, P.; MAEDA, D. L. N. F.; RODRIGUES, J. F.; BRADY, L. J.; JOHNSTON, S. A.; FERREIRA, L. C. de S.; FERREIRA, R. de C. C. LT adjuvant modulates epitope specificity and improves the efficacy of murine antibodies elicited by sublingual vaccination with the $\mathrm{N}$-terminal domain of Streptococcus mutans P1. Vaccine, v. 35, n. 52, p. 7273-7282, 2017. Disponível em: <https://doi.org/10.1016/j.vaccine.2017.11.007>.

BHATT, S.; GETHING, P.; BRADY, O.; MESSINA, J.; FARLOW, A.; MOYES, C. The global distribution and burden of dengue. NIH-PA Author Manuscript Nature, v. 496, n. 7446, p. 504-507, 2012.

BOURNAZOS, S.; RAVETCH, J. V. Diversification of IgG effector functions. International Immunology, v. 29, n. 7, p. 303-310, 2017a.

BOURNAZOS, S.; RAVETCH, J. V. Fc $\gamma$ Receptor Function and the Design of Vaccination Strategies. Immunity, v. 47, n. 2, p. 224-233, 2017b. Disponível em: <http://dx.doi.org/10.1016/j.immuni.2017.07.009>.

BRAGA, C. J. M.; RODRIGUES, J. F.; MEDINA-ARMENTEROS， Y.; FARINHA-ARCIERI, L. E. Parenteral adjuvant effects of an enterotoxigenic Escherichia coli natural heat-labile toxin variant. v. 4, n. January, p. 1-11, 2014.

BRERETON, C. F.; SUTTON, C. E.; ROSS, P. J.; IWAKURA, Y.; PIZZA, M.; RAPPUOLI, R.; ED, C.; MILLS, K. H. G. Escherichia coli Heat-Labile Enterotoxin Promotes Protective Th17 Responses against Infection by Driving Innate IL-1 and IL-23 Production. 2011.

CARDOSA, M. J. Dengue vaccine design: issues and challenges. Br Med Bull, v. 54, n. 2, p.

\footnotetext{
* De acordo com: ASSOCIAÇÃO BRASILEIRA DE NORMAS TÉCNICAS. NBR 6023: informação e
} documentação: referências: elaboração. Rio de Janeiro, 2003. 
395-405, 1998.

CHAICHANA, P.; OKABAYASHI, T.; PUIPROM, O.; SASAYAMA, M.; SASAKI, T.; YAMASHITA, A.; RAMASOOTA, P.; KUROSU, T.; IKUTA, K. Low Levels of AntibodyDependent Enhancement in Vitro Using Viruses and Plasma from Dengue Patients. PLoS ONE, v. 9, n. 3, p. e92173, 2014. Disponível em: <http://dx.plos.org/10.1371/journal.pone.0092173>.

CHAN, K. R.; ONG, E. Z; MOK, D. Z. L.; OOI, E. E. Fc receptors and their influence on efficacy of therapeutic antibodies for treatment of viral diseases. Expert review of antiinfective therapy, v. 13, n. 11, p. 1351-60, 2015. Disponível em: <http://www.ncbi.nlm.nih.gov/pubmed/26466016\%5Cnhttp://www.pubmedcentral.nih.gov/ar ticlerender.fcgi?artid=PMC4673539>.

CLEMENTS, J. D.; FREYTAG, L. C. Parenteral vaccination can be an effective means of inducing protective mucosal responses. Clinical and Vaccine Immunology, v. 23, n. 6, p. 438441, 2016.

COCKBURN, J. J. B.; NAVARRO SANCHEZ, M. E.; FRETES, N.; URVOAS, A.; STAROPOLI, I.; KIKUTI, C. M.; COFFEY, L. L.; ARENZANA SEISDEDOS, F.; BEDOUELLE, H.; REY, F. a. Mechanism of dengue virus broad cross-neutralization by a monoclonal antibody. Structure, v. 20, n. 2, p. 303-314, 2012. Disponível em: <http://dx.doi.org/10.1016/j.str.2012.01.001>.

CRILL, W. D.; ROEHRIG, J. T. Monoclonal Antibodies That Bind to Domain III of Dengue Virus E Glycoprotein Are the Most Efficient Blockers of Virus Adsorption to Vero Cells. Journal of Virology, v. 75, n. 16, p. 7769-7773, 2001. Disponível em: <http://jvi.asm.org/cgi/doi/10.1128/JVI.75.16.7769-7773.2001>.

CRUZ-OLIVEIRA, C.; FREIRE, J. M.; CONCEICAO, T. M.; HIGA, L. M.; CASTANHO, M. A. R. B.; DA POIAN, A. T. Receptors and routes of dengue virus entry into the host cells. FEMS Microbiology Reviews, v. 39, n. 2, p. 155-170, 2015a. Disponível em: <http://femsre.oxfordjournals.org/cgi/doi/10.1093/femsre/fuu004>.

CRUZ-OLIVEIRA, C.; FREIRE, J. M.; CONCEIÇÃO, T. M.; HIGA, L. M.; CASTANHO, M. A. R. B.; DA POIAN, A. T. Receptors and routes of dengue virus entry into the host cells. FEMS Microbiology Reviews, v. 39, n. 2, p. 155-170, 2015 b.

DE ALWIS, R.; SMITH, S. a.; OLIVAREZ, N. P.; MESSER, W. B.; HUYNH, J. P.; WAHALA, W. M. P. B.; WHITE, L. J.; DIAMOND, M. S.; BARIC, R. S.; CROWE, J. E.; DE SILVA, a. M. Identification of human neutralizing antibodies that bind to complex epitopes on dengue virions. Proceedings of the National Academy of Sciences, v. 109, n. 19, p. 74397444, 2012.

DELAMARRE, L.; COUTURE, R.; MELLMAN, I.; TROMBETTA, E. S. Enhancing immunogenicity by limiting susceptibility to lysosomal proteolysis. The Journal of Experimental Medicine, v. 203, n. 9, p. 2049-2055, 2006. Disponível em: <http://www.jem.org/lookup/doi/10.1084/jem.20052442>.

DONNELL, B. O.; MAURER, A.; PAPANDREOU-SUPPAPPOLA, A.; STAFFORD, P. Time-Frequency Analysis of Peptide Microarray Data: Application to Brain Cancer Immunosignatures. v. 14, p. 219-233, 2015.

EDELHOCH, H. Spectroscopic Determination of Tryptophan. 1967. 
EPITOPES, C.; CRILL, W. D.; CHANG, G. J. Localization and Characterization of Flavivirus Envelope Glycoprotein. Cell, v. 78, n. 24, p. 13975-13986, 2004.

FAN, E.; MERRITT, E. A.; VERLINDE, C. L. M. J.; HOL, W. G. J. AB 5 toxins : structures and inhibitor design. p. 680-686, 2000.

FLIPSE, J.; SMIT, J. M. The Complexity of a Dengue Vaccine: A Review of the Human Antibody Response. PLOS Neglected Tropical Diseases, v. 9, n. 6, p. e0003749, 2015. Disponível em: <http://dx.plos.org/10.1371/journal.pntd.0003749>.

FLIPSE, J.; WILSCHUT, J.; SMIT, J. M. Molecular mechanisms involved in antibodydependent enhancement of dengue virus infection in humans. Traffic, v. 14, n. 1, p. 25-35, 2013.

FRASER, S. A.; HAAN, L. De; HEARN, A. R.; BONE, H. K.; SALMOND, R. J.; RIVETT, A. J.; WILLIAMS, N. A.; HIRST, T. R.; AL, F. E. T.; MMUN, I. N. I. Mutant Escherichia coli Heat-Labile Toxin B Subunit That Separates Toxoid-Mediated Signaling and Immunomodulatory Action from Trafficking and Delivery Functions. v. 71, n. 3, p. 1527-1537, 2003.

FREYTAG, L. C.; CLEMENTS, J. D. Mucosal adjuvants. v. 23, p. 1804-1813, 2005.

GAN, E. S.; TING, D. H. R.; CHAN, K. R. The mechanistic role of antibodies to dengue virus in protection and disease pathogenesis. Expert Review of Anti-Infective Therapy, v. 15, n. 2, p. 111-119, 2017. Disponível em: 〈http://dx.doi.org/10.1080/14787210.2017.1254550〉.

GARCIA, M.; WEHBE, M.; LÉVÊQUE, N.; BODET, C. Skin innate immune response to flaviviral infection. European Cytokine Network, v. 28, n. 2, p. 41-51, 2017. Disponível em: <http://www.jle.com/download/ecn-310188-

skin_innate_immune_response_to_flaviviral_infection-institutpasteur-

WaxkU38AAQEAAFNL8GcAAAAD-u.pdf\%0Ahttp://www.jle.com/fr/revues/ecn/edocs/skin_innate_immune_response_to_flaviviral_infection_310188/article.phtml >.

GREEN, A. M.; BEATTY, P. R.; HADJILAOU, A.; HARRIS, E. Innate immunity to dengue virus infection and subversion of antiviral responses. v. 426, n. 6, p. 1148-1160, 2015.

GUILLIAMS, M.; BRUHNS, P.; SAEYS, Y.; HAMMAD, H.; LAMBRECHT, B. N. The function of $\mathrm{Fc} \gamma$ receptors in dendritic cells and macrophages. v. 14, n. February, 2014.

GUZMAN, M. G.; GUBLER, D. J.; IZQUIERDO, A.; MARTINEZ, E.; HALSTEAD, S. B. Dengue infection. Nature Reviews Disease Primers, v. 2, p. 1-26, 2016. Disponível em: <http://dx.doi.org/10.1038/nrdp.2016.55>.

GUZMAN, M. G.; HALSTEAD, S. B.; ARTSOB, H.; BUCHY, P.; FARRAR, J.; GUBLER, D. J.; HUNSPERGER, E.; KROEGER, A.; MARGOLIS, H. S.; MARTÍNEZ, E.; NATHAN, M. B.; PELEGRINO, J. L.; SIMMONS, C.; YOKSAN, S.; PEELING, R. W. Dengue: A Continuing Global Threat. Nature reviews. Microbiology, v. 8, n. 12 Suppl, p. S7-16, dez. 2010.

GUZMAN, M. G.; HARRIS, E. Dengue. The Lancet, v. 385, n. 9966, p. 453-465, 2015. Disponível em: <http://linkinghub.elsevier.com/retrieve/pii/S0140673614605729>.

HAAN, L. D. E.; HOLTROP, M.; VERWEIJ, W. R.; AGSTERIBBE, E. Mucosal immunogenicity and adjuvant activity of the recombinant A subunit of the Escherichia coli heat-labile enterotoxin. p. 706-713, 1999. 
HALPERIN, R. F.; STAFFORD, P.; EMERY, J. S.; NAVALKAR, K. A.; JOHNSTON, S. A. GuiTope : an application for mapping random- sequence peptides to protein sequences. v. $1, \mathrm{n}$. January, 2012.

HALSTEAD, S. Dengue viruses and mononuclear phagocytes. I. Infection enhancement by non-neutralizing antibody. Journal of Experimental Medicine, v. 146, n. 1, p. 201-217, 1977. Disponível em: <http://www.jem.org/cgi/doi/10.1084/jem.146.1.201〉.

HALSTEAD, S. B. Dengue Antibody-Dependent Enhancement: Knowns and Unknowns. p. $1-18,2014$.

HEINZ, F. X.; STIASNY, K. Flaviviruses and flavivirus vaccines. Vaccine, v. 30, n. 29, p. 4301-4306, $2012 . \quad$ Disponível em: <http://linkinghub.elsevier.com/retrieve/pii/S0264410X11015568>.

JENSEN, S. M, NGUYEN, C. T, AND JEWETT, J. C. HHS Public Access. J.Virol Methods, v. 235, n. 4, p. 125-130, 2016. Disponível em: <https://www.ncbi.nlm.nih.gov/pmc/articles/PMC4992633/>.

KAUFMANN, B.; ROSSMANN, M. G. Molecular mechanisms involved in the early steps of flavivirus cell entry. Microbes and Infection, v. 13, n. 1, p. 1-9, 2011. Disponível em: <http://linkinghub.elsevier.com/retrieve/pii/S1286457910002315>.

KLASSE, P. J.; SATTENTAU, Q. J. Occupancy and mechanism in anti body-mediated neutralization of animal viruses. Journal of General Virology, v. 83, n. 2002, p. 2091-2108, 2002.

KUHN, R. J.; DOWD, K. A.; BETH POST, C.; PIERSON, T. C. Shake, rattle, and roll: Impact of the dynamics of flavivirus particles on their interactions with the host. Virology, v. 479-480, p. 508-517, 2015. Disponível em: <http://dx.doi.org/10.1016/j.virol.2015.03.025>.

LASARO, M. A.; MATHIAS-SANTOS, C.; RODRIGUES, J. F.; FERREIRA, L. C. S. Functional and immunological characterization of a natural polymorphic variant of a heat-labile toxin (LT-I) produced by enterotoxigenic Escherichia coli (ETEC). FEMS Immunology \& Medical Microbiology, v. 55, n. 1, p. 93-99, jan. 2009.

LENCER, W. I.; SASLOWSKY, D. Raft trafficking of AB 5 subunit bacterial toxins. v. 1746, p. 314-321, 2005.

LEWIS, D. J. M.; HUO, Z.; BARNETT, S.; KROMANN, I.; GIEMZA, R.; GALIZA, E.; WOODROW, M.; THIERRY-CARSTENSEN, B.; ANDERSEN, P.; NOVICKI, D.; DEL, G. Transient Facial Nerve Paralysis ( Bell' s Palsy) following Intranasal Delivery of a Genetically Detoxified Mutant of Escherichia coli Heat Labile Toxin. v. 4, n. 9, p. 1-5, 2009.

LOK, S.-M.; KOSTYUCHENKO, V.; NYBAKKEN, G. E.; HOLDAWAY, H. a; BATTISTI, A. J.; SUKUPOLVI-PETTY, S.; SEDLAK, D.; FREMONT, D. H.; CHIPMAN, P. R.; ROEHRIG, J. T.; DIAMOND, M. S.; KUHN, R. J.; ROSSMANN, M. G. Binding of a neutralizing antibody to dengue virus alters the arrangement of surface glycoproteins. Nature structural \& molecular biology, v. 15, n. 3, p. 312-317, 2008.

LU, X.; LI, X.; MO, Z.; JIN, F.; WANG, B.; ZHAO, H.; SHAN, X.; SHI, L. Rapid identification of chikungunya and dengue virus by a real-time reverse transcription-loop-mediated isothermal amplification method. American Journal of Tropical Medicine and Hygiene, v. 87, n. 5, p. 947-953, 2012. 
MAEDA, D. L. N. F.; BATISTA, M. T.; PEREIRA, L. R.; DE JESUS CINTRA, M.; AMORIM, J. H.; MATHIAS-SANTOS, C.; PEREIRA, S. A.; BOSCARDIN, S. B.; DOS RAMOS SILVA, S.; FAQUIM-MAURO, E. L.; SILVEIRA, V. B.; OLIVEIRA, D. B. L.; JOHNSTON, S. A.; DE SOUZA FERREIRA, L. C.; RODRIGUES, J. F. Adjuvant-mediated epitope specificity and enhanced neutralizing activity of antibodies targeting dengue virus envelope protein. Frontiers in Immunology, v. 8, n. SEP, p. 1-13, 2017.

MALAVASI, N. V; FOGUEL, D.; BONAFE, C. F. S.; BRAGA, C. A. C. A.; CHURACHAMBI, R. M.; VIEIRA, J. M.; MORGANTI, L. Protein refolding at high pressure: Optimization using eGFP as a model. Process Biochemistry, v. 46, n. 2, p. 512-518, 2011. Disponível em: <http://dx.doi.org/10.1016/j.procbio.2010.10.002>.

MALAVIGE, G. N.; OGG, G. S. T cell responses in dengue viral infections. Journal of Clinical Virology, v. 58, n. 4, p. 605-611, 2013. Disponível em: <http://dx.doi.org/10.1016/j.jcv.2013.10.023>.

MALYALA, P.; SINGH, M. Endotoxin Limits in Formulations for Preclinical Research. v. 97, n. 6, p. 2041-2044, 2008.

MATHEW, A.; TOWNSLEY, E.; ENNIS, F. A. Elucidating the role of T cells in protection against and pathogenesis of dengue virus infections. Future Microbiology, v. 9, n. 3, p. 411$425,2014$.

MESSER, W. B.; ALWIS, R. De; YOUNT, B. L.; ROYAL, S. R.; HUYNH, J. P.; SMITH, S. a. Dengue virus envelope protein domain I / II hinge: a key target for dengue virus vaccine design? Expert Reviews Vaccines, v. 14, n. 1, p. 5-8, 2015.

MONDOTTE, J. A.; LOZACH, P.-Y.; AMARA, A.; GAMARNIK, A. V. Essential Role of Dengue Virus Envelope Protein N Glycosylation at Asparagine-67 during Viral Propagation. Journal of Virology, v. 81, n. 13, p. 7136-7148, 2007. Disponível em: <http://jvi.asm.org/cgi/doi/10.1128/JVI.00116-07>.

MUKHOPADHYAY, S.; KUHN, R. J.; ROSSMANN, M. G. A structural perspective of the flavivirus life cycle. Nature reviews. Microbiology, v. 3, n. 1, p. 13-22, 2005.

PANYA, A.; BANGPHOOMI, K.; CHOOWONGKOMON, K.; YENCHITSOMANUS, P. Peptide Inhibitors Against Dengue Virus Infection. Chemical Biology \& Drug Design, v. 84, n. 2, p. 148-157, 2014. Disponível em: <http://doi.wiley.com/10.1111/cbdd.12309>.

PASSOLD, J.; FERREIRA, S. I. A. C.; ZANETTI, C. R. Adjuvantes de vacinas : possibilidades de uso em seres humanos ou animais Vacine adjuvants: possibilities for use in humans or animals. p. 116-124, 2004.

PERERA, R.; KUHN, J. Stuctural Proteomics of Dengue Virus. Curr Opin Microbiol, v. 11, n. 4, p. 369-377, 2008.

PHYSIOL, A. J.; LIVER, G.; FEBRUARY, F.; BLOMME, B.; STEENKISTE, C. Van; GRASSI, P.; HASLAM, S. M.; CALLEWAERT, N.; VLIERBERGHE, H. Van; ZAUNER, G.; SELMAN, M. H. J.; BONDT, A.; ROMBOUTS, Y.; BLANK, D.; DEELDER, M.; WUHRER, M.; GENE, S.-; DEELDER, A. M.; HOKKE, C. H.; YAZDANBAKHSH, M.; WUHRER, M.; BLOMME, B.; STEENKISTE, C. Van; GRASSI, P.; HASLAM, S. M.; DELL, A.; CALLEWAERT, N.; VLIERBERGHE, H. Van. Alterations of serum protein N-glycosylation in two mouse models of chronic liver disease are hepatocyte and not B cell driven. n. February 2011, 2013. 
PIERSON, T. C.; DIAMOND, M. S. Molecular mechanisms of antibody-mediated neutralisation of flavivirus infection. Expert reviews in molecular medicine, v. 10, n. May, p. e12, 2008.

PIERSON, T. C.; XU, Q.; NELSON, S.; OLIPHANT, T.; GRANT, E.; FREMONT, D. H.; DIAMOND, M. S. enhancement of West Nile virus infection. Cell, v. 1, n. 2, p. 135-145, 2009a.

PIERSON, T. C.; XU, Q.; NELSON, S.; OLIPHANT, T.; GRANT, E.; FREMONT, D. H.; DIAMOND, M. S. The stoichiometry of antibody-mediated neutralization and enhancement of West Nile virus infection. Cell, v. 1, n. 2, p. 135-145, $2009 \mathrm{~b}$.

POGGIANELLA, M.; CAMPOS, J. L. S.; CHAN, K. R.; TAN, H. C.; BESTAGNO, M.; OOI, E. E.; BURRONE, O. R. Dengue e protein domain iii-based dna immunisation induces strong antibody responses to all four viral serotypes. PLoS Neglected Tropical Diseases, v. 9, n. 7, p. 1-28, 2015. Disponível em: <http://www.scopus.com/inward/record.url?eid=2-s2.084938562216\&partnerID=40\&md5=2aac9a6171719e02378fa689a69f8751>.

POKIDYSHEVA, E.; ZHANG, Y.; BATTISTI, A. J.; BATOR-KELLY, C. M.; CHIPMAN, P. R.; XIAO, C.; GREGORIO, G. G.; HENDRICKSON, W. A.; KUHN, R. J.; ROSSMANN, M. G. Cryo-EM Reconstruction of Dengue Virus in Complex with the Carbohydrate Recognition Domain of DC-SIGN. Cell, v. 124, n. 3, p. 485-493, 2006. Disponível em: <http://linkinghub.elsevier.com/retrieve/pii/S0092867406000079>.

RIVINO, L. T cell immunity to dengue virus and implications for vaccine design. Expert Review of Vaccines, v. 15, n. 4, p. 443-453, 2016. Disponível em: <http://dx.doi.org/10.1586/14760584.2016.1116948>.

ROBBIANI, D. F.; BOZZACCO, L.; KEEFFE, J. R.; KHOURI, R.; OLSEN, P. C.; GAZUMYAN, A.; SCHAEFER-BABAJEW, D.; AVILA-RIOS, S.; NOGUEIRA, L.; PATEL, R.; AZZOPARDI, S. A.; UHL, L. F. K.; SAEED, M.; SEVILLA-REYES, E. E.; AGUDELO, M.; YAO, K. H.; GOLIJANIN, J.; GRISTICK, H. B.; LEE, Y. E.; HURLEY, A.; CASKEY, M.; PAI, J.; OLIVEIRA, T.; WUNDER, E. A.; SACRAMENTO, G.; NERY, N.; ORGE, C.; COSTA, F.; REIS, M. G.; THOMAS, N. M.; EISENREICH, T.; WEINBERGER, D. M.; DE ALMEIDA, A. R. P.; WEST, A. P.; RICE, C. M.; BJORKMAN, P. J.; REYES-TERAN, G.; KO, A. I.; MACDONALD, M. R.; NUSSENZWEIG, M. C. Recurrent Potent Human Neutralizing Antibodies to Zika Virus in Brazil and Mexico. Cell, v. 169, n. 4, p. 597-609.e11, 2017. Disponível em: <http://dx.doi.org/10.1016/j.cell.2017.04.024>.

RODENHUIS-ZYBERT, I. A.; VAN DER SCHAAR, H. M.; DA SILVA VOORHAM, J. M.; VAN DER ENDE-METSELAAR, H.; LEI, H.-Y. Y.; WILSCHUT, J.; SMIT, J. M. Immature dengue virus: a veiled pathogen? PLoS Pathogens, v. 6, n. 1, p. e1000718, 2010. Disponível em:

$<$ http://www.pubmedcentral.nih.gov/articlerender.fcgi?artid=2798752\&tool=pmcentrez\&rend ertype $=$ abstract $>$.

RODRIGUES, J. F.; MATHIAS-SANTOS, C.; SBROGIO-ALMEIDA, M. E.; AMORIM, J. H.; CABRERA-CRESPO, J.; BALAN, A.; FERREIRA, L. C. S. Functional diversity of heatlabile toxins (LT) produced by enterotoxigenic Escherichia coli: Differential enzymatic and immunological activities of LT1 (hLT) and LT4 (pLT). Journal of Biological Chemistry, v. 286, n. 7, p. 5222-5233, 2011.

RYAN, E. J.; NEELA, E. M. C.; MURPHY, G. A.; STEWART, H.; HAGAN, D. O.; PIZZA, M.; RAPPUOLI, R.; MILLS, K. H. G. Mutants of Escherichia coli Heat-Labile Toxin Act as 
Effective Mucosal Adjuvants for Nasal Delivery of an Acellular Pertussis Vaccine : Differential Effects of the Nontoxic AB Complex and Enzyme Activity on Th1 and Th2 Cells. v. 67, n. 12, p. 6270-6280, 1999.

SCHEIBLHOFER, S.; LAIMER, J.; MACHADO, Y.; WEISS, R.; THALHAMER, J. Influence of protein fold stability on immunogenicity and its implications for vaccine design. Expert Review of Vaccines, v. 16, n. 5, p. 479-489, 2017. Disponível em: <https://doi.org/10.1080/14760584.2017.1306441>.

SCHIEFFELIN, J. S.; COSTIN, J. M.; NICHOLSON, C. O.; ORGERON, N. M.; FONTAINE, K. a; ISERN, S.; MICHAEL, S. F.; ROBINSON, J. E. Neutralizing and non-neutralizing monoclonal antibodies against dengue virus E protein derived from a naturally infected patient. Virology journal, v. 7, n. M, p. 28, 2010.

SCHMIDT, A. G.; YANG, P. L.; HARRISON, S. C. Peptide Inhibitors of Dengue-Virus Entry Target a Late-Stage Fusion Intermediate. PLoS Pathogens, v. 6, n. 4, p. e1000851, 2010. Disponível em: <http://dx.plos.org/10.1371/journal.ppat.1000851〉.

SCREATON, G.; MONGKOLSAPAYA, J.; YACOUB, S.; ROBERTS, C. New insights into the immunopathology and control of dengue virus infection. Nature Reviews Immunology, v. 15, n. 12, p. 745-759, 2015. Disponível em: <http://dx.doi.org/10.1038/nri3916>.

SKALICKOVA, S.; HEGER, Z.; KREJCOVA, L.; PEKARIK, V.; BASTL, K.; JANDA, J.; KOSTOLANSKY, F.; VARECKOVA, E.; ZITKA, O.; ADAM, V.; KIZEK, R. Perspective of use of antiviral peptides against influenza virus. Viruses, v. 7, n. 10, p. 5428-5442, 2015.

SMIT, J. M.; MOESKER, B.; RODENHUIS-ZYBERT, I.; WILSCHUT, J. Flavivirus cell entry and membrane fusion. Viruses, v. 3, n. 2, p. 160-171, 2011.

SPROKHOLT, J.; HELGERS, L. C.; GEIJTENBEEK, T. B. H. Innate immune receptors drive dengue virus immune activation and disease. Future Virology, v. 13, n. 4, p. 287-305, 2018.

ST. JOHN, A. L.; ABRAHAM, S. N.; GUBLER, D. J. Barriers to preclinical investigations of anti-dengue immunity and dengue pathogenesis. Nature Reviews Microbiology, v. 11, n. 6, p. 420-426, 2013. Disponível em: <http://dx.doi.org/10.1038/nrmicro3030>.

STAFFORD, P.; CICHACZ, Z.; WOODBURY, N. W.; JOHNSTON, S. A. Immunosignature system for diagnosis of cancer. Proceedings of the National Academy of Sciences, v. 111, n. 30, p. E3072-E3080, 2014. <http://www.pnas.org/cgi/doi/10.1073/pnas.1409432111>.

STIASNY, K.; KIERMAYR, S.; HOLZMANN, H.; HEINZ, F. X. Cryptic properties of a cluster of dominant flavivirus cross-reactive antigenic sites. Journal of virology, v. 80, n. 19, p. 9557-9568, 2006.

SUKUPOLVI-PETTY, S.; AUSTIN, S. K.; PURTHA, W. E.; OLIPHANT, T.; NYBAKKEN, G. E.; SCHLESINGER, J. J.; ROEHRIG, J. T.; GROMOWSKI, G. D.; BARRETT, A. D.; FREMONT, D. H.; DIAMOND, M. S. Type- and subcomplex-specific neutralizing antibodies against domain III of dengue virus type 2 envelope protein recognize adjacent epitopes. Journal of virology, v. 81, n. 23, p. 12816-26, 2007. Disponível em: <http://www.pubmedcentral.nih.gov/articlerender.fcgi?artid=2169112\&tool=pmcentrez\&rend ertype $=$ abstract $>$.

VAN DER SCHAAR, H. M.; WILSCHUT, J. C.; SMIT, J. M. Role of antibodies in controlling dengue virus infection. Immunobiology, v. 214, n. 7, p. 613-629, 2009. Disponível em: 
<http://linkinghub.elsevier.com/retrieve/pii/S0171298508001472>.

VANBLARGAN, L. A.; GOO, L.; PIERSON, T. C. Deconstructing the Antiviral NeutralizingAntibody Response: Implications for Vaccine Development and Immunity. Microbiology and molecular biology reviews, v. 80, n. 4, p. 989-1010, 2016. Disponível em: <http://www.ncbi.nlm.nih.gov/pubmed/27784796>.

VANUSA, P.; CONCEIC, F. R.; DELlAGOSTIN, O. A.; DOOLAN, D. L. Non-toxic derivatives of LT as potent adjuvants. v. 29, p. 1538-1544, 2011.

WAGNER, D.; WITH, K. De; HUZLY, D.; HUFERT, F.; WEIDMANN, M.; BREISINGER, S.; EPPINGER, S. Nosocomial Acquisition of. v. 10, n. 10, 2004.

WAHALA, W. M. P. B.; KRAUS, A. A.; HAYMORE, L. B.; ACCAVITTI-LOPER, M. A.; DE SILVA, A. M. Dengue virus neutralization by human immune sera: Role of envelope protein domain III-reactive antibody. Virology, v. 392, n. 1, p. 103-113, 2009. Disponível em: <http://dx.doi.org/10.1016/j.virol.2009.06.037>.

WANG, Z; LI, L.; PENNINGTON, J. G.; SHENG, J.; YAP, M. L.; PLEVKA, P.; MENG, G.; SUN, L.; JIANG, W.; ROSSMANN, M. G. Obstruction of dengue virus maturation by Fab fragments of the $2 \mathrm{H} 2$ antibody. Journal of virology, v. 87, n. 16, p. 8909-15, 2013. Disponível em:

$<$ http://www.pubmedcentral.nih.gov/articlerender.fcgi?artid=3754034\&tool=pmcentrez\&rend ertype $=$ abstract $>$.

WATTERSON, D.; ROBINSON, J.; CHAPPELL, K. J.; BUTLER, M. S.; EDWARDS, D. J.; FRY, S. R.; BERMINGHAM, I. M.; COOPER, M. A.; YOUNG, P. R. A generic screening platform for inhibitors of virus induced cell fusion using cellular electrical impedance. Scientific Reports, v. 6, n. March, p. 1-9, 2016. Disponível em: $<$ http://dx.doi.org/10.1038/srep22791>.

WEISKOPF, D.; SETTE, A. T-cell immunity to infection with dengue virus in humans. Frontiers in Immunology, v. 5, n. MAR, p. 1-6, 2014.

WEN, J.; SHRESTA, S. T Cell Immunity to Zika and Dengue Viral Infections. Journal of Interferon \& Cytokine Research, v. 37, n. 11, p. 475-479, 2017. Disponível em: <http://online.liebertpub.com/doi/10.1089/jir.2017.0106>.

WHITEHEAD, S. S.; BLANEY, J. E.; DURBIN, A. P.; MURPHY, B. R. Prospects for a dengue virus vaccine. Nature Reviews Microbiology, v. 5, n. 7, p. 518-528, 2007. Disponível em: 〈http://www.nature.com/doifinder/10.1038/nrmicro1690>.

WILLIAMS, K. L.; SUKUPOLVI-PETTY, S.; BELTRAMELLO, M.; JOHNSON, S.; SALLUSTO, F.; LANZAVECCHIA, A.; DIAMOND, M. S.; HARRIS, E. Therapeutic Efficacy of Antibodies Lacking Fc $\gamma R$ against Lethal Dengue Virus Infection Is Due to Neutralizing Potency and Blocking of Enhancing Antibodies. PLoS Pathogens, v. 9, n. 2, 2013.

XU, Y.; ZHANG, H.; XU, X. Enhancement of vaccine potency by fusing modified LTK63 into human papillomavirus type 16 chimeric virus-like particles. FEMS Immunology and Medical Microbiology, v. 52, n. 1, p. 99-109, 2008.

YAM-PUC, J. C.; CEDILLO-BARRÓN, L.; AGUILAR-MEDINA, E. M.; RAMOS-PAYÁN, R.; ESCOBAR-GUTIÉRREZ, A.; FLORES-ROMO, L. The cellular bases of antibody responses during dengue virus infection. Frontiers in Immunology, v. 7, n. JUN, p. 1-12, 2016. 
YAUCH, L. E.; ZELLWEGER, R. M.; KOTTURI, M. F.; QUTUBUDDIN, A.; SIDNEY, J.; PETERS, B.; PRESTWOOD, T. R.; SETTE, A.; SHRESTA, S. A Protective Role for Dengue Virus-Specific CD8+ T Cells. J Immunol., v. 182, n. 8, p. 4865-4873, 2010.

ZELLWEGER, R. M.; PRESTWOOD, T. R.; SHRESTA, S. Enhanced infection of liver sinusoidal endothelial cells in a mouse model of antibody-induced severe dengue disease. Cell host \& microbe, v. 7, n. 2, p. 128-139, 2010.

ZELLWEGER, R. M.; TANG, W. W.; EDDY, W. E.; KING, K.; SANCHEZ, M. C.; SHRESTA, S. CD8 ${ }^{+}$T Cells Can Mediate Short-Term Protection against Heterotypic Dengue Virus Reinfection in Mice. Journal of Virology, v. 89, n. 12, p. 6494-6505, 2015. Disponível em: 〈http://jvi.asm.org/lookup/doi/10.1128/JVI.00036-15>.

ZHANG, C. Y.; BOOTH, J. W. Cell Biology: Divergent Intracellular Sorting of Fe $\gamma$ RIIA and Fc $\gamma$ RIIB2 Christine Y. Zhang and James W. Booth. p. 34250-34258, 2010.

ZHANG, X.; GE, P.; YU, X.; BRANNAN, J. M.; BI, G.; ZHANG, Q.; SCHEIN, S.; ZHOU, Z. H. Cryo-EM structure of the mature dengue virus at $3.5-\AA$ resolution. Nature Structural $\&$ Molecular Biology, v. 20, n. 1, p. 105-110, 2012. Disponível em: <http://www.nature.com/doifinder/10.1038/nsmb.2463>. 